\title{
Investigating Relationships between Reproduction, Immune Defenses, and Cortisol in Dall Sheep
}

\author{
Cynthia J. Downs ${ }^{1 *}$, Brianne V. Boan ${ }^{2 \dagger}$, Thomas D. Lohuis ${ }^{3}$ and Kelley M. Stewart ${ }^{2}$ \\ ${ }^{1}$ Department of Biology, Hamilton College, Clinton, NY, United States, ${ }^{2}$ Department of Natural Resources and \\ Environmental Sciences, University of Nevada, Reno, NV, United States, ${ }^{3}$ Alaska Department of Fish and Game, \\ Anchorage, AK, United States
}

\section{OPEN ACCESS}

Edited by:

Andrew Steven Flies,

University of Tasmania, Australia

Reviewed by:

Jorge Contreras-Garduño, Universidad Nacional Autónoma

de México, Mexico

Frederic Levy,

Institut national de la Recherche

Agronomique (INRA), France

*Correspondence:

Cynthia J. Downs

cdowns@hamilton.edu

tPresent address: Brianne V. Boan,

U.S. Forest Service, Sierraville,

CA, United States

Specialty section: This article was submitted to

Comparative Immunology,

a section of the journal

Frontiers in Immunology

Received: 29 August 2017 Accepted: 12 January 2018

Published: 31 January 2018

Citation:

Downs CJ, Boan BV, Lohuis TD and Stewart KM (2018) Investigating

Relationships between

Reproduction, Immune Defenses, and Cortisol in Dall Sheep.

Front. Immunol. 9:105. doi: 10.3389/fimmu.2018.00105
Life-history theory is fundamental to understanding how animals allocate resources among survival, development, and reproduction, and among traits within these categories. Immediate trade-offs occur within a short span of time and, therefore, are more easily detected. Trade-offs, however, can also manifest across stages of the life cycle, a phenomenon known as carryover effects. We investigated trade-offs on both time scales in two populations of Dall sheep (Ovis dalli dalli) in Southcentral Alaska. Specifically, we (i) tested for glucocorticoid-mediated carryover effects from the breeding season on reproductive success and immune defenses during parturition and (ii) tested for tradeoffs between immune defenses and reproduction within a season. We observed no relationship between cortisol during mating and pregnancy success; however, we found marginal support for a negative relationship between maternal cortisol and neonate birth weights. Low birth weights, resulting from high maternal cortisol, may result in low survival or low fecundity for the neonate later in life, which could result in overall population decline. We observed a negative relationship between pregnancy and bacterial killing ability, although we observed no relationship between pregnancy and haptoglobin. Study site affected bactericidal capacity and the inflammatory response, indicating the influence of external factors on immune responses, although we could not test hypotheses about the cause of those differences. This study helps advance our understanding of the plasticity and complexity of the immune system and provides insights into the how individual differences in physiology may mediate differences in fitness.

Keywords: allocation theory, carryover effect, constitutive immunity, glucocorticoids, immune defenses, Ovis dalli dalli, reproduction, trade-offs

\section{INTRODUCTION}

Life-history theory is fundamental to understanding how animals allocate resources among lifehistory traits including performance traits and physiological functions that contribute to survival $(1,2)$. Immediate trade-offs occur within a short span of time and, therefore, are more easily detected. Trade-offs, however, can also manifest across multiple stages of the life cycle, a phenomenon known as carryover effects (3). That is, events during one stage of the life cycle may influence allocation decisions of an individual during another stage of the life cycle. For example, capital breeders finance their reproduction from energy stores gained in months prior to the mating season $(4,5)$. Generally, individuals with larger fat stores upon initiation of reproduction have the greatest reproductive success (6) and those who initiate reproduction with insufficient energy stores pay a fitness cost of 
reduced offspring survival $(3,7,8)$. Because fat reserves at the time of reproduction depend upon previously acquired resources, events that affect resource acquisition in one season carry over and subsequently affect the energy available for reproduction (9). Similar logic dictates that allocation of resources to physiological functions, such as immune defenses, may be influenced by carryover effects, and physiological mechanisms, such as integrative hormone signaling networks, may mediate these effects across seasons $(10,11)$.

Survival and reproduction are two key life-history traits, and selection should result in optimal investment in processes that contribute to both (1). Because immune defenses contribute to survival, energetic and nutritional costs of maintaining and mounting immune defenses are included within the optimality equation for life histories (12-14). The effects of collateral damage from immune responses, that is immunopathology, are also included within these optimality equations of life history $(15,16)$. As a consequence of the expense of immune defenses, individuals are often unable to maintain both a high level of immune function and successfully reproduce when limited resources force a trade-off in allocation between these two physiological processes $(14,15,17,18)$. Nonetheless, life-history strategy may dictate whether an individual reduces investment in reproduction in favor of immune defenses in a given year (16). Many species reduce immune defenses when committed to reproduction (17-22). However, manifestation of these trade-offs may depend on an individual's energetic state and be regulated facultatively, and it may depend on overall life history strategy $(16,17)$. Large herbivores often exhibit tradeoffs between current and future reproduction, rather than between reproduction and survival (1, 23-25). Thus, individuals from slow-paced species should favor investment in traits that enhance survival, such as immune defenses, when resources are limited $(6,26,27)$.

Availability of energetic and nutritional resources mediate trade-offs between immunological and reproductive performance mechanistically through integrative physiological networks and shared signaling molecules $(15,28)$. Specifically, key integrators in physiological pathways may act as the mechanism by which carryover effects mediate differences among individuals in investment in immune function and reproduction $(11,15,29)$. Glucocorticoids are one proposed integrator of carryover effects (30). Glucocorticoids are released to support metabolically demanding activities and, as such, their circulating concentrations change during predictable seasonal and life-cycle events and they increase in response to stressful events (31-34). As part of the signaling pathway that mediates immune defenses and reproduction, acute increase of glucocorticoids facilitates reproduction and stimulate or redistribute immunological defenses $(28,33,35,36)$. However, sustained, elevated concentrations of glucocorticoids that are indicative of chronic stress can suppress immune defenses, prevent pregnancy, and lower juvenile survival by reducing birth weight of neonates $(31,35,37-39)$. In brief, glucocorticoids can alter the cost-benefit equation of investment in immune defenses (28).

Changes in glucocorticoid levels during one stage of the life cycle may affect events during another stage (30). Specifically, high levels of glucocorticoids during mating may reduce reproductive success in large ungulates in two ways. First, integrated long-term levels of glucocorticoids may indicate elevated energy expenditure $(40,41)$, and females with high energy expenditures during the mating season may have fewer resources to invest in reproduction. Alternatively, high levels of glucocorticoids during the mating season may indicate chronic stress unrelated to energetic demands, and high, chronic stress levels can suppress reproduction regardless of energetic constraints $(31,33,41)$.

During pelage growth, glucocorticoids from blood are deposited into hair of mammals and evidence suggest that hair glucocorticoids represents systemic-levels of circulating free glucocorticoids (42-44). Thus, glucocorticoid concentrations in pelage represent a non-invasive measure of integrated blood concentrations during pelage growth and provide researchers with the opportunity to study carryover effects by providing information about physiological state during a life event prior to sample collection $(41,45)$. Briefly, hair glucocorticoid concentrations are sensitive to major prolonged stressors and are correlated with changes in circulating glucocorticoids observed during pregnancy $(43,46,47)$. However, single acute events of high glucocorticoids are not reflected in hair glucocorticoid concentrations (48). Thus, measurements of hair glucocorticoids provide a good indicator of energetically demanding or stressful events experienced during pelage growth (43). In most large mammals, pelage growth during the autumn occurs concurrently with the mating season, and thus provides an indicator of an individual's state when allocation decisions about reproduction were made.

We studied two populations of Dall sheep (Ovis dalli dalli) in Southcentral Alaska to investigate (i) trade-offs between immune defenses and reproduction within a season and (ii) carryover effects mediated by glucocorticoids on reproduction in a longlived, slow-paced species. Dall sheep are large ungulates that reside in highly seasonal environments throughout mountainous regions in Alaska and northwestern Canada. They produce a maximum of one offspring per year. We focused on an energy allocation framework because Dall sheep are capital breeders that live in a seasonal environment and, after mating in the fall, undergo gestation during the winter months when food is scarce. They undergo parturition beginning in May and lactate into the early autumn (49). Capital breeders like Dall sheep rely on stored energy reserves for the majority of their energy during the winter, their annual cycles are organized around gaining energy stores in the summer to fuel survival and reproduction in the winter, and their ecology makes energy trade-offs likely (50). We focused on constitutive immunity because these defenses are always present, they represent the first line of physiological defense against an invading pathogen, and they can mediate the outcome of some infections $(51,52)$. Specifically, we quantified bactericidal capacity and haptoglobin. Bactericidal capacity provides a broad assessment of host immune ability to eliminate bacterial pathogens $(53,54)$. Haptoglobin is a protein marker that is generally interpreted as a biomarker of an individual's ability to upregulate inflammation (55). The inflammatory response is a cascade involving acute phase proteins that recruit cells and molecules to destroy pathogens (55-57). 
Both energy constraints and elevated glucocorticoids can serve as mechanisms that underlie a potential carryover effect from autumn to spring that can reduce pregnancy and constitutive immune function. Thus, we expect that high glucocorticoid levels in the autumn will reduce the probability of parturition in the spring. The timing of our measurements means that our measure of reproduction integrates the probability of becoming pregnant, probability of successful parturition if pregnant, and probability of the neonate surviving until the time of capture. Specifically, we hypothesized (i) that individuals that are non-pregnant in the spring would have had higher glucocorticoid levels during the previous autumn than those that are pregnant in the spring and (ii) that within pregnant individuals, high glucocorticoid levels in the autumn would lead to reduced birth weights of neonates in the spring. Because we expect this slow-paced species to invest in survival (i.e., immune defenses) over reproduction, we did not expect pregnant individuals to reduce constitutive immunity relative to non-pregnant individuals.

\section{MATERIALS AND METHODS}

\section{Study Area}

We studied two populations of Dall sheep in Southcentral Alaska in the Chugach range. One population was within Alaska Department of Fish and Game's game management unit 14C
(GMU 14C) and the other was within game management unit 13D (GMU 13D). The units are approximately $76.5 \mathrm{~km}$ apart and separated by a prominent glaciers (Figure 1). Dominant vegetation is similar in both study areas and changes with elevation; black spruce (Picea mariana) and alder (Alnus spp.) occur at lower elevations and short alpine forbs (e.g., mountain avens, Dryas octopetala) and grasses (e.g., alpine timothy, Phleum alpinum) occur at higher elevations. Most sheep in the study resided between 914 and 1,829 $\mathrm{m}$ in elevation.

GMU 14C lies within the Chugach State Park northeast of Anchorage and is comprised of five drainages and their surrounding ridges: Goat Creek, Eklutna, Peters Creek, Eagle River, and Ship Creek. GMU 14C is bordered by Anchorage and the town of Eagle River to the west, the Knik arm and river to the North, and the Turnagain arm to the South. The total study area is approximately $800 \mathrm{~km}^{2}$. From the weather station closest to GMU 14C, the 30-year (1981-2010) mean annual temperature was about $2.4^{\circ} \mathrm{C}$, mean annual snowfall was $189.23 \mathrm{~cm}$, and mean annual precipitation was $41.91 \mathrm{~cm}$ (58).

GMU 13D is northeast of GMU 14C and lies between the Matanuska Glacier and Tazlina Lake and is bordered to the north-northwest by the Alaska State Highway 1. GMU 13D is comprised of several mountain groups separated from each other by three prominent glaciers-Powell, Nelchina, and Tazlinathat limit movement within the study unit. The total study area

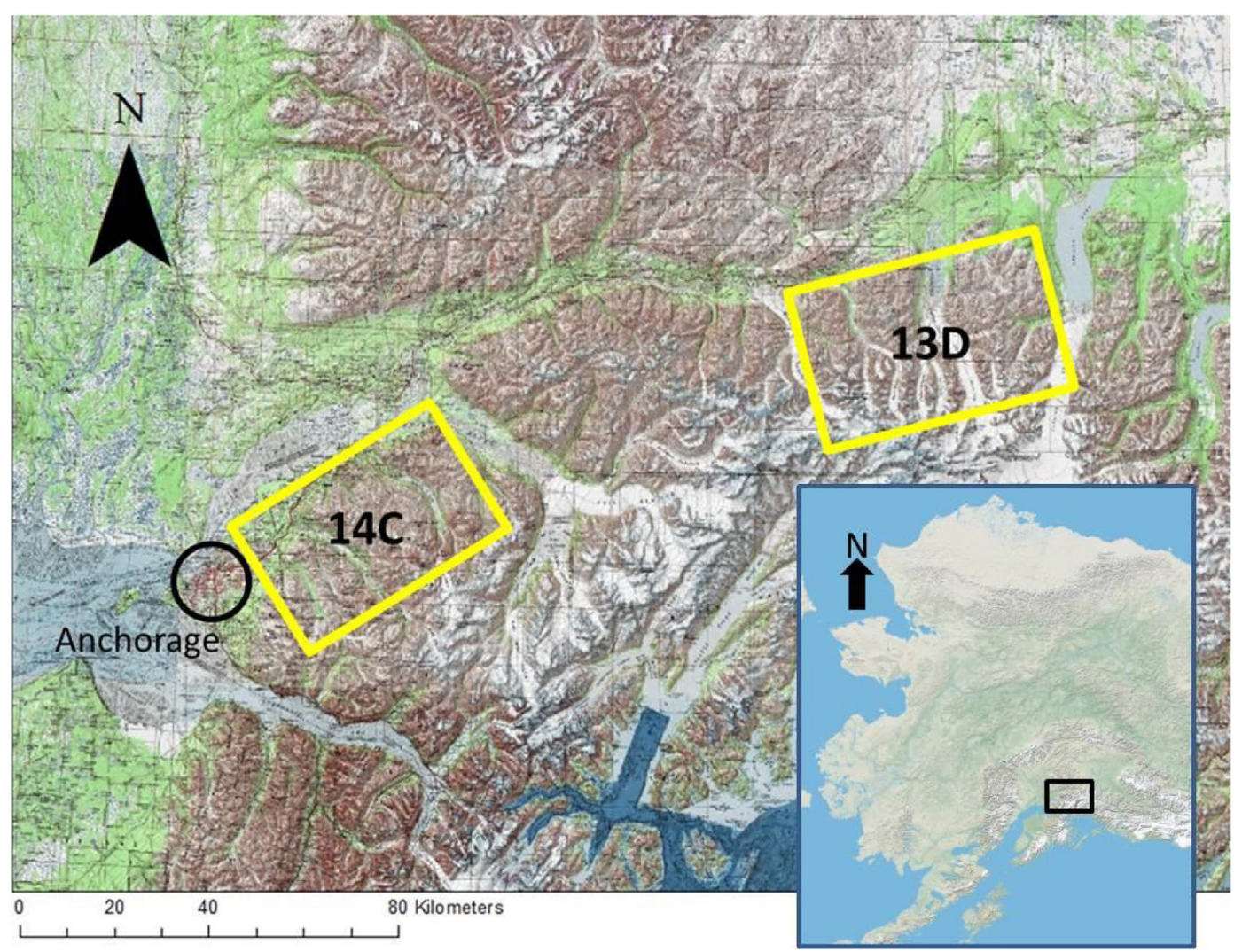

FIGURE 1 | Map of study areas GMU 14C and GMU 13D in the Chugach Range, AK. Anchorage is within the black circle. The map inlay of Alaska shows approximate location of the study units within the state. 
is approximately $925 \mathrm{~km}^{2}$. From the weather stations closest to GMU13D, the 30-year (1981-2010) mean annual temperature was $-2.17^{\circ} \mathrm{C}$, mean annual snowfall was $167.13 \mathrm{~cm}$, and mean annual precipitation was $41.33 \mathrm{~cm}$ (58).

\section{Field Methods}

In 2012 and 2013, we captured sheep using standard helicopter and netgun techniques (59), and marked individuals with Telonics VHF radio collars. We attempted to recapture the same individuals each year, however, inaccessible terrain and weather conditions hindered capture efforts of some individuals. During capture, we collected blood samples (2012 and 2013) to determine pregnancy status and to quantify immune defenses, and hair samples (2013 only) to quantify cortisol levels. We determined pregnancy by testing blood serum for the presence of pregnancy specific protein B (BioTracking LLC, Moscow, ID, USA) $(25,60$, 61). We determined age using horn growth rings (62). A body condition score was assigned based on the amount of bony structural protrusions felt in the rump, spine, neck, and shoulders (63). Scores ranged from 0 to 5 with 0 representing no subcutaneous fat and five representing individuals with substantial fat reserves (63). All radio-tagged animals were monitored once to twice per week from March to early May when parturition occurred. We attempted to monitor females every day during the parturition season (approximately May 7 to June 10) to detect and capture neonates. Neonates were captured on the ground on foot, collared with Telonics VHF radio collars, weighed (to the nearest $0.1 \mathrm{~kg}$ ), and sex was determined. Age in days was estimated based on umbilical cord presence and condition, pelage coloration, and mobility. As neonates age, the umbilical cord dries and usually has fallen off by 3 days of age (T. Lohuis, personal observation). At the time of birth, neonate pelage has a gray appearance and lightens with age (T. Lohuis, personal observation). In addition, Dall sheep neonates are precocial and quickly gain stability and mobility with increasing age $(64,65)$, and we were often limited to capturing neonates between 0 and 5 days old because of this. We did not recapture adult females at the same time that we captured neonates.

\section{Ethical Statement}

All aspects of this research were approved by the Institutional Animal Care and Use Committee at the University of Nevada Reno (Protocol \#2012-00542) and Alaska Department of Fish and Game (Protocols \#2009-13 and \#2012-024). All methods were in keeping with protocols adopted by the American Society of Mammalogists for field research involving mammals (66). Use of Escherichia coli was approved by the Institutional Biosafety Committee at University of Nevada Reno (B2013-10) and methods were in keeping with recommendations in $\mathrm{CDC} / \mathrm{NIH}$ Guidelines.

\section{Immune Assays}

The bacteria killing ability assay was used to quantify bactericidal capacity of circulating, constitutive components of immune defenses in plasma-complement, acute phase proteins, and natural antibodies $(54,67)$. We performed assays on serum samples, following Zysling et al. (68) and calibrated for Dall sheep.
We used E. coli (Epower Microorganisms \#0483E7, ATCC8739, MicroBioLogics, St. Cloud, MN, USA) as our ecologically relevant pathogen. Briefly, we mixed $100 \mu \mathrm{l}$ of a sample with $100 \mu \mathrm{l}$ of Luria Bertani (LB) broth to make a 1:2 dilution of serum solution and then added $20 \mu \mathrm{l}$ of our working $E$. coli solution $(\sim 5,000$ bacteria $\mathrm{ml}^{-1}$ ). We made two positive controls by mixing $200 \mu \mathrm{LB}$ broth with $20 \mu \mathrm{l}$ of working E. coli solution. Samples and controls were vortexed and incubated at $37^{\circ} \mathrm{C}$ for $30 \mathrm{~min}$. We vortexed samples and controls and plated $50 \mu \mathrm{l}$ aliquots onto LB agar in petri dishes in triplicate to help ensure reproducibility. One positive control was plated at the beginning and end of each batch. Plates were incubated overnight at $37^{\circ} \mathrm{C}$, after which bacteria colonies were counted. We used all six positive control plates (three replicates of two controls) to determine the mean number of control colonies for a particular batch, and samples were compared with the positive controls from their batch. Bactericidal capacity was calculated as percent bacteria killed relative to the positive control. To better ensure reproducibility, we calculated mean intra-control coefficient of variance (CV); it was $8.8 \%$. It was inappropriate to look at $\mathrm{CV}$ of number of colony forming units on sample plates because small changes in the number of colonies among plates when there are few colonies results in very high CVs.

We measured haptoglobin concentrations in serum to assess potential for an inflammatory response. Functionally, haptoglobin is an acute phase protein that binds to heme preventing it from serving as a nutrient for pathogens and initiating deleterious oxidation reactions resulting in a rapid inflammatory response $(55,56,69)$. Haptoglobin is normally present at low constitutive levels but increases when a pathogen is encountered (70). Because constitutive haptoglobin concentrations are predictive of haptoglobin concentrations after an endotoxin challenge (55), they are indicative of ability to mount an inflammatory response. We assessed haptoglobin presence in raw serum samples (i.e., not diluted) using the Phase Range Haptoglobin Assay Cat. N. TP-801 (Second Generation; Tridelta Development Ltd., Maynooth, Ireland) $(55,71)$. We followed the manufactures instructions. We ran 16 samples twice to check for reproducibility, the mean CV for these was $13.4 \%$. Mean intra-sample CV was $2 \%$.

\section{Cortisol Assays}

We quantified cortisol levels from hair samples collected from 44 individuals in 2013. Cortisol is the dominant glucocorticoid in bighorn sheep (Ovis canadensis), another wild sheep species (72). To prepare hair for cortisol extraction, the hair was washed twice in isopropanol, dried, and ground to a powder using a ball mill (SPEX SamplePrep 8000M Mixer/Mill, Metuchen, NJ, USA). Ground hair samples were $\sim 0.05 \mathrm{~g}$ and weighed to the nearest $0.0001 \mathrm{~g}$. We then added $1 \mathrm{ml}$ of methanol to each sample, rocked samples for $24 \mathrm{~h}$, and centrifuged them at 2,000 rpm for $1 \mathrm{~min}$. We pipetted $0.6 \mathrm{ml}$ of the supernatant into a vial, evaporated the sample on a heat block at $37^{\circ} \mathrm{C}$ under nitrogen. The residual cortisol from the sample was reconstituted with $1,040 \mu \mathrm{l}$ of a $95 \%$ assay diluent from the kit and 5\% methanol mixture. We quantified cortisol levels using a commercially available kit (Salametrics Salivary Cortisol EIA kit, product \#1-3002) (46), following modifications for hair samples suggested by Davenport et al. (46) and Koren et al. (42). Before quantifying samples, we verified that 
the kit worked for hair samples from Dall sheep by checking for parallelism between an unknown dilution curve and the standard curve (73). We used a high and low standard provided with the kit as an inter-assay control and we re-quantified all the samples on a plate if these controls were not within the expected range. We re-quantified samples if the coefficient of variation between replicates was greater than $15 \%$.

\section{Statistical Methods}

All statistics were performed in SAS (v. 9.3, SAS Inst 2010). We assessed variation in pregnancy rates between years and study sites using the $Z$-test for proportions that allowed sampling with replacement (74). The $Z$-test was appropriate because we attempted to capture the same individuals each year, and no new animals were added to the study after the first year of capture. We used Pearson correlations (Proc CORR) to determine the repeatability of our immune measure across years and to determine the correlation between our immune measures within year. We used untransformed data for all correlations.

We determined the effect of pregnancy status on bactericidal capacity and haptoglobin concentrations using generalized linear models (Proc GLM), with a separate model for each year. We analyzed each year separately because not all individuals were captured in both years. We transformed bactericidal capacity from percent to angular arcsine square root to improve normality of residuals (74). We included study site and body condition score as main effects for both bactericidal capacity and haptoglobin concentration. To account for possible senescence, we included age as a predictor variable of bactericidal capacity and haptoglobin concentrations using linear regression weighted by sample size (74). We did not find a relationship and, therefore, did not include age in further analyses of constitutive immunity.

To determine the effect of cortisol during the autumn on pregnancy status (binomial response: pregnant or not pregnant) the following spring, we used logistic regression (Proc Logistic) and included study site and spring body condition score as dependent variables alongside cortisol. During the preliminary analysis, we also included age as a predictor variable of pregnancy but did not find a relationship and, therefore, did not include age in the final analysis.

To calculate neonate birth weight, we used linear regression to estimate weight gained per day and back calculated birth weight based on age and weight of the neonate at capture. We then determined the effect of cortisol during the autumn on neonate birth weight during the spring with analysis of covariance (Proc GLM). We included maternal age, maternal body condition during the spring, study site, and cortisol concentration as explanatory variables. We also determined the effects of a maternal haptoglobin or bactericidal capacity during pregnancy on birth weights of neonates using separate linear regressions (Proc REG). Significance was determined at $\alpha=0.05$; however, we consider patterns intriguing at $\alpha=0.1$ because of our small sample sizes.

\section{RESULTS}

The number of adult female sheep and lambs we captured for each GMU during 2012 and 2013 are presented in Table 1. Adult female ages ranged from 2 to 11 years and body condition scores ranged from 1.75 to 2.75 . Overall pregnancy rates were higher in 2013 (0.833) than in $2012(0.378)(Z=4.31, P<0.0001)$, and this pattern held for both GMUs (Table 1; Figure 2). Pregnancy rates did not differ between study sites in either year (2012: $Z=0.503$, $P=0.615 ; 2013: Z=-0.092, P=0.927$, Figure 2 ).

\section{Immune Defenses}

We had bactericidal capacity data from 91 samples and haptoglobin data from 87 samples; our samples were spread fairly evenly among sites and years (Table 2). Haptoglobin had an 18\% repeatability when data were combined across sites, but was not repeatable when only $13 \mathrm{D}$ or $14 \mathrm{C}$ were examined independently. Bactericidal capacity had a 53\% repeatability in GMU 14C, but was not repeatable across years in $13 \mathrm{D}$ or when all data were combined (Table 3). Haptoglobin levels were not correlated with bactericidal capacity within a year for either site or all the data combined (Table 3).

Mean bactericidal capacity was $74.0 \pm 27.4 \%$ during 2012 and $76.2 \pm 27.7 \%$ during 2013. In 2012, bactericidal capacity was not associated with pregnancy status $\left(F_{1,45}=0.52, P=0.476\right)$, body condition $\left(F_{3,40}=0.200, P=0.896\right)$, or study site $\left(F_{1,45}=2.41\right.$, $P=0.128)$. Similarly, we observed no relationship between

TABLE 1 | Description of number of adult female and neonate Dall sheep captured in each of the study areas (GMU) for each year in the Chugach Range, AK 2012-2013.

\begin{tabular}{ccccc}
\hline Year & GMU & $\begin{array}{c}\text { Adult females } \\
\text { captured }\end{array}$ & Pregnancy rate & Neonates captured \\
\hline 2012 & $13 D$ & 31 & 0.32 & 14 \\
& $14 C$ & 34 & 0.44 & 26 \\
\hline 2013 & $13 D$ & 26 & 0.83 & 26 \\
& $14 C$ & 22 & 0.86 & 11
\end{tabular}

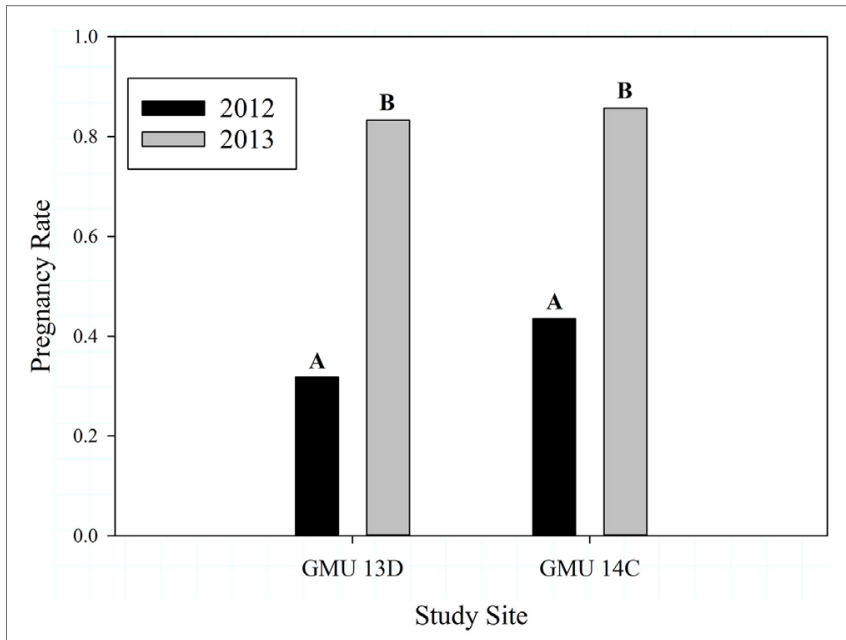

FIGURE 2 | Dall sheep pregnancy rates for years 2012 and $2013(Z=4.31$, $P<0.0001)$ and study sites $(2012 Z=0.503, P=0.615 ; 2013 Z=-0.092$, $P=0.927)$ in the Chugach Range, AK. Letters over bars indicate results of comparisons following a significant $Z$-test, where different letters are statistically different. 
body condition and bactericidal capacity in $2013\left(F_{2,41}=0.690\right.$, $P=0.507)$. In 2013, however, bactericidal capacity was significantly greater in GMU $14 \mathrm{C}$ than GMU $13 \mathrm{D}\left(F_{1,45}=5.050\right.$, $P=0.030$; Figure 3A), and there was an intriguing pattern of a negative effect of pregnancy status on bacterial killing ability $\left(F_{1,45}=3.19, P=0.081\right.$; Figure 3B; overall model $F_{2,45}=3.99$, $P=0.026)$. Bactericidal capacity was not significantly associated with neonate birth weight $\left(F_{1,13}=1.89, P=0.193, n=15\right)$.

TABLE 2 | Samples sizes for immune assays and the cortisol assay by year and site in the Chugach Range, AK 2012-2013.

\begin{tabular}{lcccc}
\hline Site & Year & Bacteria killing assay & Haptoglobin & Cortisol \\
\hline All data & & 91 & 87 & 44 \\
$14 C$ & 2012 & 22 & 21 & $\mathrm{~N}^{\mathrm{a}}$ \\
& 2013 & 24 & 25 & 22 \\
$13 \mathrm{D}$ & 2012 & 23 & 20 & $\mathrm{~N} / \mathrm{A}$ \\
& 2013 & 22 & 21 & 22 \\
\hline
\end{tabular}

aWe did not quantify cortisol concentrations in 2012.

TABLE 3 | Repeatability of immune assays between years and correlations between immune traits within years for all data combined and data from each study areas (GMU).

\begin{tabular}{lllrrr}
\hline Sites & Variable 1 & Variable 2 & $\boldsymbol{r}$ & $\boldsymbol{P}$-value & $\boldsymbol{n}$ \\
\hline Both GMUs & BKA 2012 & BKA 2013 & 0.258 & 0.176 & 29 \\
& Hapt 2012 & Hapt 2013 & $-\mathbf{0 . 1 8 0}$ & $\mathbf{0 . 0 3 6}$ & $\mathbf{2 8}$ \\
& BKA 2012 & Hapt 2012 & -0.015 & 0.938 & 28 \\
& BKA 2013 & Hapt 2013 & -0.062 & 0.748 & 29 \\
13D only & BKA 2012 & BKA 2013 & 0.126 & 0.967 & 13 \\
& Hapt 2012 & Hapt 2013 & -0.308 & 0.263 & 15 \\
& BKA 2012 & Hapt 2012 & -0.058 & 0.845 & 14 \\
& BKA 2013 & Hapt 2013 & -0.119 & 0.687 & 14 \\
14C only & BKA 2012 & BKA 2013 & $\mathbf{0 . 5 3 2}$ & $\mathbf{0 . 0 3 4}$ & $\mathbf{1 6}$ \\
& Hapt 2012 & Hapt 2013 & 0.485 & 0.093 & 13 \\
& BKA 2012 & Hapt 2012 & 0.213 & 0.465 & 14 \\
& BKA 2013 & Hapt 2013 & 0.100 & 0.724 & 15
\end{tabular}

BKA, bactericidal capacity assay; Hapt, haptoglobin.

Bold results indicate significant correlations.
In 2012, haptoglobin did not differ between sites $\left(F_{1,41}=0.79\right.$, $P=0.381)$, and was not associated with pregnancy status $\left(F_{1,45}=1.16, P=0.287\right)$ or body condition $\left(F_{2,41}=0.180, P=0.832\right)$. In 2013, haptoglobin concentration was significantly greater in GMU $13 \mathrm{D}$ than $14 \mathrm{C}\left(F_{1,46}=4.64, P=0.037\right.$, Figure 4A); this is the opposite of the pattern observed for bactericidal capacity between sites. In 2013, haptoglobin was not significantly predicted by pregnancy status $\left(F_{1,41}=0.45, P=0.506\right.$, Figure 4B) or body condition $\left(F_{3,37}=0.630, P=0.598\right)$. Haptoglobin levels were not significantly associated with neonate birth $\left(F_{1,13}=0.89\right.$, $P=0.362, n=15)$.

\section{Cortisol}

We quantified concentrations of cortisol from 44 samples; those samples were evenly distributed between the two study sites (Table 2). In 2013, logistic regression was $65.8 \%$ concordant and indicated that pregnancy status during the spring was not associated with cortisol during the previous autumn (Wald ChiSquare $=1.275, P=0.259)$, body condition during the spring (Wald Chi-Square $=1.331, P=0.249$ ), or study site (Wald ChiSquare $=0.008, P=0.9298$ ). There was a marginal negative trend between maternal cortisol during the autumn mating season and neonate birth weight the following spring $\left(F_{1,11}=4.79, P=0.057\right.$, Figure 5). Adult age $\left(F_{1,11}=1.000, P=0.547\right)$, spring body condition $\left(F_{1,11}=2.70, P=0.146\right)$, and study site $\left(F_{1,11}=1.14\right.$, $P=0.317)$ did not explain birth weight of neonates during spring.

\section{DISCUSSION}

We tested for glucocorticoid-mediated carryover effects on reproductive success. We also tested for trade-offs between immune defenses and reproduction within a season. We observed no relationship between maternal cortisol and pregnancy success; however, we found marginal support for a negative relationship between maternal cortisol and neonate birth weights, providing weak evidence of a carryover effect. We observed a weak negative relationship between pregnancy and bacterial killing ability
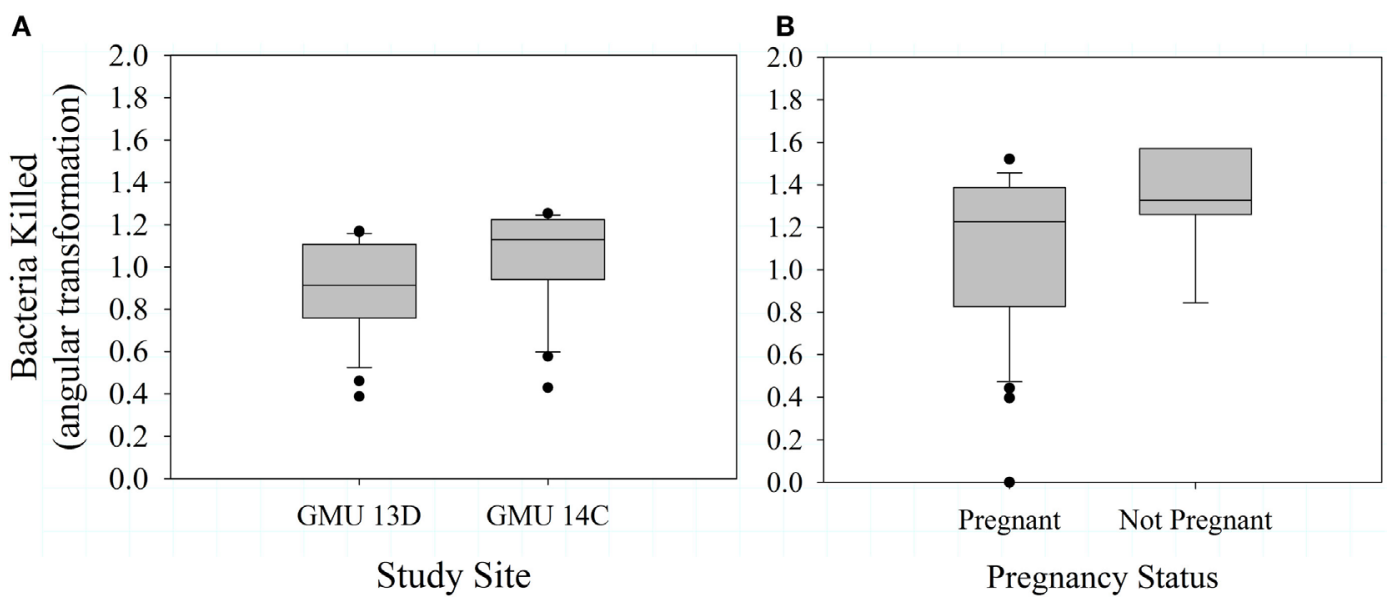

FIGURE 3 | Mean ( \pm SE) bactericidal capacity for female Dall sheep by study sites in the Chugach Range, AK (A) and pregnancy status (B). Samples were collected in 2013 


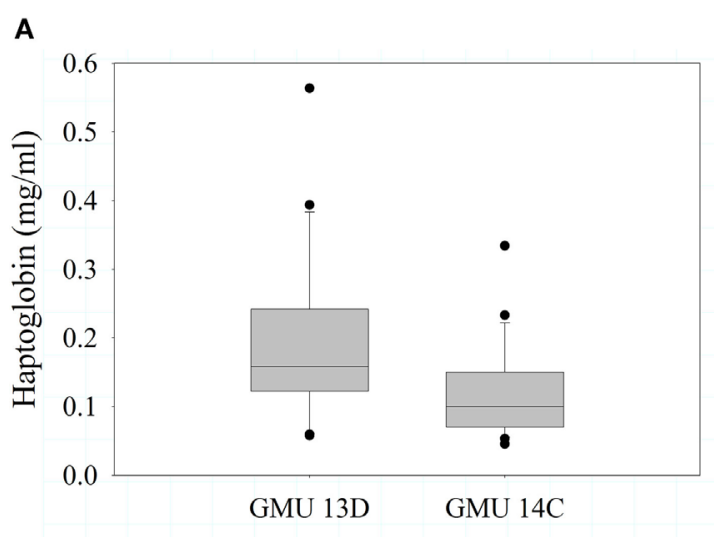

Study Site

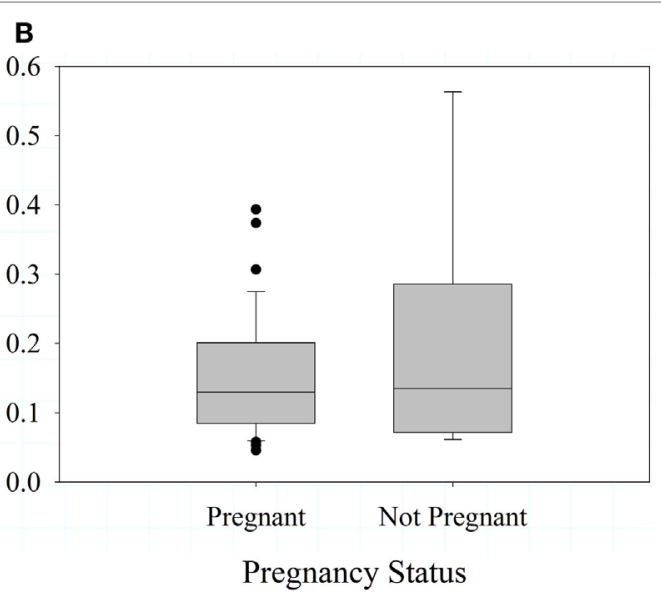

FIGURE 4 | Mean ( \pm SE) haptoglobin concentrations in female Dall sheep by study sites in the Chugach Range, AK (A) and pregnancy status (B). Sample were collected 2013.

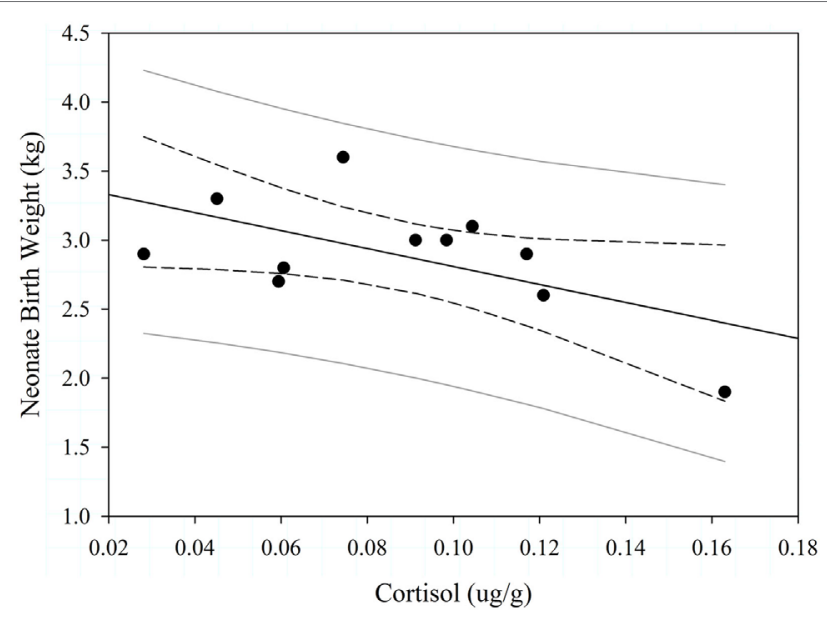

FIGURE 5 | Effect of maternal cortisol levels on Dall sheep neonate birth weight $(n=11)$ in the Chugach Range, AK, 2013. The dashed lines are the 95\% confidence limits and gray solid lines are the 95\% prediction limits.

during 1 year of our study providing evidence of a trade-off, although we observed no relationship between pregnancy and haptoglobin. We also found that constitutive immunity differed between sites and years highlighting the plasticity of immune defenses.

\section{Carryover Effects Mediated by Cortisol}

We found no evidence of cortisol mediating the ability to become pregnant during the mating season in autumn 2012. Because pregnancy rates were low in the spring of 2012, few sheep underwent the energetically expensive processes of gestation, parturition, and lactation prior to the 2012 autumn mating season. Females in autumn 2012 were likely in better condition going into the mating season because of so few individuals produced offspring the previous year $(6,23)$. Because females in good nutritional condition are more likely to conceive and maintain pregnancy
$(6,23)$, the low pregnancy rate in 2012 may have led to the high pregnancy rate of spring 2013. If our interpretation is correct, these data would provide evidence of a carryover effect between years, and they corroborate a pattern commonly found in capital breeders with large body sizes (23-25).

Cortisol levels observed during autumn may not have been high enough to affect pregnancy, but we found weak evidence that they were high enough to affect fetal development. Even though we had a small sample of body weights of neonates, we observed that cortisol levels of mothers during autumn were weakly and inversely correlated with birth weights of neonates born the following spring. The effect of maternal cortisol during mating on offspring mass potentially has longer-term implications of reducing success of offspring because low birth weight has been shown to reduce survival of young and lower fecundity during adulthood $(75,76)$. Furthermore, in highly seasonal environments, like Alaska, young with low birth weight have rarely been observed to catch up in body mass with the larger individuals in their cohorts $(77,78)$, and larger adults tend to have higher fitness (79). Therefore, the disadvantage of being born small may carry throughout the individual's lifetime.

\section{Pregnancy and Immune Defenses: Evidence of a Carryover Effect?}

Parturition in Dall sheep occurs in June. We captured adult female sheep in mid-March, and during that stage of the annual cycles, females are not provisioning offspring (i.e., lactating) from the previous year and because lactation is energetically expensive and most are relying on stored fat for energy because environmental food sources are not readily available (80). Although pregnancy status was not significantly associated with either measure of constitutive immunity in 2012, we observed an interesting trend in 2013, whereby sheep that were pregnant had lower bactericidal capacity than those that were not pregnant $(P<0.1)$. Although our sample sizes were small, the trend suggesting a relationship between pregnancy and bactericidal capacity is worth examining further in future studies. 
If generalizable, this trend suggests that Dall sheep approaching parturition invest fewer resources in immune response in favor of reproduction, as has been seen in numerous fast-paced species (17-21). Published results about trade-offs between immune defenses and pregnancy in slow-paced ungulates are ambiguous. Pregnant N'Dama cows maintained under traditional husbandry practices in Gambia had higher rates of Trypanosomiasis than non-pregnant cows (81), indicating a difference in underlying physiology or behavior. Similarly, free-ranging Soay sheep (Ovis aries) with higher concentrations of antinuclear antibodies, an indicator of immune defenses, had lower siring probability and lower female breeding probability (82), although this study is not a direct comparison to ours because we instigated how pregnancy affected constitutive immunity rather than investigating how constitutive immunity affected probability of pregnancy. In contrast, pregnancy status did not affect hemolytic-complement activities or bactericidal activity in free-ranging North American elk (Cervus elaphus) (26), nor did it affect bactericidal capacity in free-ranging African buffalo (Syncerus caffer). These contradictory results suggest that an immune trade-off with reproduction may depend on the immune defense measured, timing of the measurement, and other external variables that regulate traits such as physiological condition and hormone concentrations. Mechanistically, and as previously discussed, the negative trend between pregnancy and immune defenses in 2013 could arise from a carryover effect that is likely mediated by an individual's energy budget.

As pregnancy progresses, some studies show that constitutive immune defense decline $(83,84)$. Other studies have shown that immunity shifts from humoral to cell-mediated responses as pregnancy progresses (85-87), although those studies focused on adaptive rather than innate immune responses. Our results are consistent with both of those patterns, because we found that humoral measures of constitutive immunity were lower in sheep late in their pregnancy. These shifts in immune strategy might be facilitated by hormones that mediate pregnancy. The physiology mediating pregnancy alone, however, is unlikely to explain our results because we did not find a significant difference in immune defenses between pregnant and non-pregnant sheep in both years. That is, our incontinent results over years may indicate a facultative strategy caused by a reconfiguration of the immune system to increase probability of a successful reproductive event while taking into account other cues such as body condition $(17,28,87)$.

\section{Population and Individual-Level Patterns in Immune Defenses}

Immune defenses are highly plastic and change between years, seasons, and even weeks (88-90). Immune assays in our study exhibited repeatability across years for only 2 of the 8 analyses we performed, and those repeatabilities suggested an upper limit of additive genetics of only 54 and $18 \%$ (Table 3). Similarly, a study of captive red knots (Calidris canutus) showed that microbiocidal activity for three microbes, white blood cell differentials, hemolytic and hemogglutination activity changed across the annual cycle (88). In addition, T-cell-mediated immunocompetence of free-ranging, nesting tress swallows was influenced by weather within a single nestling season (89).
Constitutive bactericidal capacity and constitutive haptoglobin concentrations of plasma differed between sites during 2013, and interestingly, bactericidal capacity and haptoglobin concentrations showed opposite trends between the two sites. In 2013, sheep from GMU 13D had higher haptoglobin concentrations and lower bactericidal capacity relative to sheep from GMU 14C. These results add to a growing number of studies that have found population-level differences in constitutive immunity. At the same spatial scale of our study, other studies have linked differences in constitutive immunity to group-level differences in mean physiological state (26), parasite prevalence (91), population characteristics such as density $(26,92)$, habitat quality $(92,93)$, and weather (89). We cannot distinguish among these alternative possibilities with our data.

Interestingly, neither immune response was related to body condition as measured by body condition scores. These results have two possible explanations. First, body condition scores alone are a coarse measure of body condition and likely are subject to observer bias $(94,95)$. Therefore, body condition score may not be a precise enough measure to correlate with physiological traits, like immune defenses. Second, we observed little variation in body condition scores. The range of fat scores was 1.75-2.75 on a 6-point scale, and thus the sheep were generally in medium to low nutritional condition, and none were in high condition (63). The range of condition scores is likely related to the season in which we captured individuals. In strongly seasonal environments, as in our study, all individuals lose weight and decline in body condition even when fed ad libitum because they use stored fat for energy (96). At the time of capture, sheep were likely in the lowest condition of the annual cycle because we captured at the end of winter (80).

\section{CONCLUSION}

Our correlative results suggest extrinsic factors, including study site, play a larger role in mediating immunocompetence than the intrinsic factors studied (reproduction and body condition). This finding corroborates previous work that found local environmental conditions can overwhelm the genetic signature of immune defenses (89). We found weak evidence that high maternal cortisol levels are correlated with low neonate birth weights. Thus, our results have implications for understanding how individuallevel differences in chronic glucocorticoids concentrations and individual-differences in immune defenses may affect population dynamics by affecting fitness components (97).

Although interpretation of our results is limited by the complexity of a natural system and the difficulties of studying a natural system in rough terrain and harsh weather conditions, we argue, as others do $(98,99)$, that studying immunological defenses in free-ranging animals is important for understanding dysfunction of the immune system. Immune defenses and pathologies are the product of genotype by environment interactions and these interactions are hard to replicate in laboratory conditions (100-103). For example, a high level of pathogen exposure causes wild mice (Mus musculus domesticus) to have immune systems that are in a highly activated or primed state relative to those of laboratory mice (104). Furthermore, the implications for population dynamics are 
hard to extrapolate from laboratory studies. In general, lessons about immunological responses in wild, free-ranging animals will help advance our understanding of the plasticity and complexity of the immune system and enhance our understanding of disease and its effects on population dynamics.

\section{ETHICS STATEMENT}

All aspects of this research were approved by the Institutional Animal Care and Use Committee at the University of Nevada Reno (Protocol \#2012-00542) and Alaska Department of Fish and Game (Protocols \#2009-13 and \#2012-024). All methods were in keeping with protocols adopted by the American Society of Mammalogists for field research involving mammals (Sikes, Gannon \& Amer Soc 2011). Use of Escherichia coli was approved by the Institutional Biosafety Committee at University of Nevada Reno (B2013-10) and methods were in keeping with recommendations in $\mathrm{CDC} / \mathrm{NIH}$ Guidelines.

\section{AUTHOR CONTRIBUTIONS}

TL and KS designed the field component of the study and obtained funding for the project. $\mathrm{CD}, \mathrm{KS}$, and $\mathrm{BB}$ designed the laboratory portion of the study. BB and TL conducted field

\section{REFERENCES}

1. Stearns SC. The Evolution of Life Histories. New York, NY, USA: Oxford University Press (1992). 264 p.

2. Van Noordwijk AJ, De Jong G. Acquisition and allocation of resources: their influence on variation in life-history tactics. Am Nat (1986) 128:137-42. doi:10.1086/284547

3. Harrison XA, Blount JD, Inger R, Norris DR, Bearhop S. Carry-over effects as drivers of fitness differences in animals. J Anim Ecol (2011) 80:4-18. doi:10.1111/j.1365-2656.2010.01740.x

4. Drent RH, Daan S. The prudent parent: energetic adjustments in avian breeding. Ardea (1980) 68:225-52.

5. Houston AI, McNamara JM, Barta Z, Klasing KC. The effect of energy reserves and food availability on optimal immune defence. Proc Biol Sci (2007) 274:2835-42. doi:10.1098/rspb.2007.0934

6. Monteith KL, Bleich VC, Stephenson TR, Pierce BM, Conner MM, Kie JG, et al. Life-history characteristics of mule deer: effects of nutrition in a variable environment. Wildl Monogr (2014) 186:1-62. doi:10.1002/wmon.1011

7. Ebbinge BS, Spaans B. The importance of body reserves accumulated in spring staging areas in the temperate zone for breeding in dark-bellied brent geese Branta b. bernicla in the high Arctic. J Avian Biol (1995) 26:105-13. doi: $10.2307 / 3677058$

8. Rughetti M, Dematteis A, Meneguz PG, Festa-Bianchet M. Age-specific reproductive success and cost in female Alpine ibex. Oecologia (2015) 178:197-205. doi:10.1007/s00442-014-3192-3

9. Festa-Bianchet M. Condition-dependent reproductive success in bighorn ewes. Ecol Lett (1998) 1:91-4. doi:10.1046/j.1461-0248.1998.00023.x

10. Flatt T, Heyland A, Stearns SC. What mechanistic insighs can or cannot contribute to life history evolution: an exchange between Stearns, Heyland, and Flatt. In: Flatt T, Heyland A, editors. Mechanisms of Life History Evolution: The Genetics and Physiology of Life History Traits and Trade-offs. New York, NY, USA: Oxford University Press (2011). p. 375-9.

11. Cohen AA, Martin LB, Wingfield JC, McWilliams SR, Dunne JA. Physiological regulatory networks: ecological roles and evolutionary constraints. Trends Ecol Evol (2012) 27:428-35. doi:10.1016/j.tree.2012.04.008

12. Downs CJ, Stewart KM. A primer in ecoimmunology and immunology for wildlife research and management. Calif Fish Game (2014) 100:371-95. work and collected samples for physiological assays. $\mathrm{CD}$ and $\mathrm{BB}$ calibrated assays for Dall sheep, and BB performed all laboratory assays, $\mathrm{CD}, \mathrm{BB}$, and $\mathrm{KS}$ analyzed those data and wrote the manuscript. All authors contributed substantially to editing the manuscript and approved the final version.

\section{ACKNOWLEDGMENTS}

We thank J. S. Sedinger and T. P. Albright for their editorial input and statistical advice. We thank our pilots, M. Meekins, M. Litzen, T. Levanger, J. Fieldman, T. Cambrier, and B. Silvey, for their excellent flying skills in spotting, tracking, and capturing sheep. We also thank ADFG staff M. Harrington, J. Coltrane, C. Brockman, D. Battle, D. Saalfeld, K. Smith, W. Schock, and C. Stantorf for their speedy assistance in lamb captures. We thank E. Clark for her help in the lab. We thank A. Flies and two anonymous referees for comments on an earlier version of this manuscript.

\section{FUNDING}

This study was supported by an Alaska Department of Fish and Game grant, a Hatch grant awarded by Nevada Agriculture Experimental Station, and funding from the University of Nevada Reno awarded to KS.
13. Lochmiller RL, Deerenberg C. Trade-offs in evolutionary immunology: just what is the cost of immunity? Oikos (2000) 88:87-98. doi:10.1034/j.1600-0706.2000.880110.x

14. Sheldon BC, Verhulst S. Ecological immunology: costly parasite defences and tradeoffs in evolutionary ecology. Trends Ecol Evol (1996) 11:317-21. doi:10.1016/0169-5347(96)10039-2

15. Downs CJ, Adelman JS, Demas GE. Mechanisms and methods in ecoimmunology: integrating within-organism and between-organism processes. Integr Comp Biol (2014) 54:340-52. doi:10.1093/icb/icu082

16. Lee KA. Linking immune defenses and life history at the levels of the individual and the species. Integr Comp Biol (2006) 46:1000-15. doi:10.1093/icb/ icl049

17. French SS, DeNardo DF, Moore MC. Trade-offs between the reproductive and immune systems: facultative responses to resources or obligate responses to reproduction? Am Nat (2007) 170:79-89. doi:10.1086/518569

18. French SS, Johnston GIH, Moore MC. Immune activity suppresses reproduction in food-limited female tree lizards Urosaurus ornatus. Funct Ecol (2007) 21:1115-22. doi:10.1111/j.1365-2435.2007.01311.x

19. Ilmonen P, Taarna T, Hasselquist D. Experimentally activated immune defence in female pied flycatchers results in reduced breeding success. Proc R Soc Lond B Biol Sci (2000) 267:665-70. doi:10.1098/rspb.2000.1053

20. Cox RM, Parker EU, Cheney DM, Liebl AL, Martin LB, Calsbeek R. Experimental evidence for physiological costs underlying the trade-off between reproduction and survival. Funct Ecol (2010) 24:1262-9. doi:10.1111/j. 1365-2435.2010.01756.x

21. Råberg L, Nilsson J, Ilmonen $\mathrm{P}$, Stjernman M, Hasselquist D. The cost of an immune response: vaccination reduces parental effort. Ecol Lett (2000) 3:382-6. doi:10.1046/j.1461-0248.2000.00154.x

22. Bonneaud C, Mazuc J, Gonzalez G, Haussy C, Chastel O, Faivre B, et al. Assessing the cost of mounting an immune response. Am Nat (2003) 161:367-79. doi:10.1086/346134

23. Morano S, Stewart KM, Sedinger JS, Nicolai CA, Vavra M. Life-history strategies of North American elk: trade-offs associated with reproduction and survival. J Mammal (2013) 94:162-72. doi:10.1644/12-MAMM-A-074.1

24. Parker KL, Barboza PS, Gillingham MP. Nutrition integrates environmental responses of ungulates. Funct Ecol (2009) 23:57-69. doi:10.1111/j.1365-2435.2009.01528.x 
25. Stewart KM, Bowyer RT, Dick BL, Johnson BK, Kie JG. Density-dependent effects on physical condition and reproduction in North American elk: an experimental test. Oecologia (2005) 143:85-93. doi:10.1007/s00442-004-1785-y

26. Downs CJ, Stewart KM, Dick BL. Investment in constitutive immune function: effects of density-dependent processes. PLoS One (2015) 10:e0125586. doi:10.1371/journal.pone. 0125586

27. Wobeser GA. Disease in Wild Animals: Investigation and Management. 2nd ed. Berlin, Germany: Springer Verlag (2010).

28. Adamo SA. The stress response and immune system share, borrow, and reconfigure their physiological network elements: evidence from the insects. Horm Behav (2017) 88:25-30. doi:10.1016/j.yhbeh.2016.10.003

29. Martin LB, Burgan S, Adelman JS, Gervasi SS. Host competence: an organismal trait to integrate immunology and epidemiology. Integr Comp Biol (2016) 56:1225-37. doi:10.1093/icb/icw064

30. Schultner J, Moe B, Chastel O, Tartu S, Bech C, Kitaysky AS. Corticosterone mediates carry-over effects between breeding and migration in the kittiwake Rissa tridactyla. Mar Ecol Prog Ser (2014) 496:125-33. doi:10.3354/meps10603

31. Wingfield JC, Romero LM. Adrenocortical responses to stress and their modulation in free-living vertebrates. In: McEwen BS, editor. Handbook of Physiology, Section 7: The Endocrine System, Volume 4: Coping with the Environment: Neural and Endocrine Mechanisms. New York, NY: Oxford University Press (2000). p. 211-36.

32. Romero LM, Romero RC. Corticosterone responses in wild birds: the importance of rapid initial sampling. Condor (2002) 104:129-35. doi:10.1650/00105422(2002)104[0129:CRIWBT]2.0.CO;2

33. Sapolsky RM, Romero LM, Munck AU. How do glucocorticoids influence stress responses? Integrating permissive, suppressive, stimulatory, and preparative actions. Endocr Rev (2000) 21:55-89. doi:10.1210/edrv.21.1.0389

34. Romero LM, Meister CJ, Cyr NE, Kenagy GJ, Wingfield JC. Seasonal glucocorticoid responses to capture in wild free-living mammals. Am J Physiol Regul Integr Comp Physiol (2008) 294:R614-22. doi:10.1152/ajpregu.00752.2007

35. Martin LB. Stress and immunity in wild vertebrates: timing is everything. Gen Comp Endocrinol (2009) 163:70-6. doi:10.1016/j.ygcen.2009.03.008

36. Dhabhar F, McEwen B. Acute stress enhances while chronic stress suppresses cell-mediated immunity in vivo: a potential role for leukocyte trafficking. Brain Behav Immun (1997) 11:286-306. doi:10.1006/brbi.1997.0508

37. Cameron R. Reproductive pauses by female caribou. J Mammal (1994) 75:10-3. doi:10.2307/1382230

38. Festa-Bianchet M, Jorgenson J, Luchierini M, Wishart W. Life-history consequences of variation in age of primiparity in bighorn ewes. Ecology (1995) 76:871-81. doi:10.2307/1939352

39. Singer F, Harting A, Symonds K, Coughenour M. Density dependence, compensation, and environmental effects on elk calf mortality in Yellowstone National Park. J Wildl Manage (1997) 61:12-25. doi:10.2307/3802410

40. Waterhouse MD, Sjodin B, Ray C, Erb L, Wilkening J, Russello MA. Individualbased analysis of hair corticosterone reveals factors influencing chronic stress in the American pika. Ecol Evol (2017) 7:4099-108. doi:10.1002/ece3.3009

41. Romero LM, Fairhurst GD. Measuring corticosterone in feathers: strengths, limitations, and suggestions for the future. Comp Biochem Physiol Part A Mol Integr Physiol (2016) 202:112-22. doi:10.1016/j.cbpa.2016.05.002

42. Koren L, Mokady O, Karaskov T, Klein J, Koren G, Geffen E. A novel method using hair for determining hormonal levels in wildlife. Anim Behav (2002) 63:403-6. doi:10.1006/anbe.2001.1907

43. Russell E, Koren G, Rieder M, Van Uum S. Hair cortisol as a biological marker of chronic stress: current status, future directions and unanswered questions. Psychoneuroendocrinology (2012) 37:589-601. doi:10.1016/j. psyneuen.2011.09.009

44. Harkey MR. Anatomy and physiology of hair. Forensic Sci Int (1993) 63:9-18. doi:10.1016/0379-0738(93)90255-9

45. Warne RW, Proudfoot GA, Crespi EJ. Biomarkers of animal health: integrating nutritional ecology, endocrine ecophysiology, ecoimmunology, and geospatial ecology. Ecol Evol (2015) 5:557-66. doi:10.1002/ece3.1360

46. Davenport M, Tiefenbacher S, Lutz C, Novak M, Meyer J. Analysis of endogenous cortisol concentrations in the hair of rhesus macaques. Gen Comp Endocrinol (2006) 147:255-61. doi:10.1016/j.ygcen.2006.01.005

47. Kirschbaum C, Tietze A, Skoluda N, Dettenborn L. Hair as a retrospective calendar of cortisol production-increased cortisol incorporation into hair in the third trimester of pregnancy. Psychoneuroendocrinology (2009) 34:32-7. doi:10.1016/j.psyneuen.2008.08.024
48. Ashley N, Barboza P, Macbeth B, Janz D, Cattet M, Booth R, et al. Glucocorticosteroid concentrations in feces and hair of captive caribou and reindeer following adrenocorticotropic hormone challenge. Gen Comp Endocrinol (2011) 172:382-91. doi:10.1016/j.ygcen.2011.03.029

49. Festa-Bianchet M. Individual differences, parasites, and the costs of reproduction for bighorn ewes (Ovis canadensis). J Anim Ecol (1989) 58:785-95. doi:10.2307/5124

50. Festa-Bianchet M, Jorgenson J, King W, Smith K, Wishart W. The development of sexual dimorphism: seasonal and lifetime mass changes in bighorn sheep. Can J Zool (1996) 74:330-42. doi:10.1139/z96-041

51. Schmid-Hempel P, Ebert D. On the evolutionary ecology of specific immune defence. TrendsEcolEvol (2003) 18:27-32. doi:10.1016/S0169-5347(02)00013-7

52. Millet S, Bennett J, Lee KA, Hau M, Klasing KC. Quantifying and comparing constitutive immunity across avian species. Dev Comp Immunol (2007) 31:188-201. doi:10.1016/j.dci.2006.05.013

53. French SS, DeNardo DF, Greives TJ, Strand CR, Demas GE. Human disturbance alters endocrine and immune responses in the Galapagos marine iguana (Amblyrhynchus cristatus). Horm Behav (2010) 58:792-9. doi:10.1016/j. yhbeh.2010.08.001

54. Demas GE, Zysling DA, Beechler BR, Muehlenbein MP, French SS. Beyond phytohaemagglutinin: assessing vertebrate immune function across ecological contexts. J Anim Ecol (2011) 80:710-30. doi:10.1111/j.1365-2656.2011. 01813.x

55. Matson KD, Horrocks NP, Versteegh MA, Tieleman BI. Baseline haptoglobin concentrations are repeatable and predictive of certain aspects of a subsequent experimentally-induced inflammatory response. Comp Biochem Physiol A Mol Integr Physiol (2012) 162:7-15. doi:10.1016/j.cbpa.2012.01.010

56. Dobryszycka W. Biological functions of haptoglobin - new pieces to an old puzzle. Eur J Clin Chem Clin Biochem (1997) 35:647-54

57. Murphy KP, Travers P, Walport M. Janeway's Immunobiology. Garland Science (2007). $928 \mathrm{p}$.

58. Alaska Climate Research Center. Climate Normal. (2017).

59. Krausman P, Hervet J, Ordway L. Capturing deer and mountain sheep with a net-gun. Wildl Soc Bull (1985) 13:71-3.

60. Noyes JH, Sasser RG, Johnson BK, Bryant LD, Alexander B. Accuracy of pregnancy detection by serum protein (PSPB) in elk. Wildl Soc Bull (1997) 25:695-8.

61. Keech MA, Bowyer RT, Ver Hoef JM, Boertje RD, Dale BW, Stephenson TR. Life-history consequences of maternal condition in Alaskan moose. J Wildl Manag (2000) 64:450-62. doi:10.2307/3803243

62. Geist V. Validity of horn segment counts in aging bighorn sheep. J Wildl Manag (1966) 30:634-5. doi:10.2307/3798763

63. Stephenson TR, Bleich VC, Pierce BM, Mulcahy GP. Validation of mule deer body composition using in vivo and post-mortem indices of nutritional condition. Wildl Soc Bull (2002) 30:557-64.

64. Bowyer RT, Leslie DMJ, Rachlow JL. Dall's and Stone's sheep. In: Demaris S, Krausman PR, editors. In Ecology and Management of Large Mammals in North America. Upper Saddle River, New Jersey: Prentice-Hall Press (2000). p. 491-516.

65. Pitzman M. Birth Behavior and Lamb Survival in Mountain Sheep in Alaska. Ph.D. thesis, University of Alaska Fairbanks, Fairbanks, Alaska (1970).

66. Sikes RS, Gannon WL, Amer Soc M. Guidelines of the American Society of Mammalogists for the use of wild mammals in research. J Mammal (2011) 92:235-53. doi:10.1644/10-MAMM-F-355.1

67. Tieleman IB, Williams JB, Ricklefs RE, Klasing KC. Constitutive innate immunity is a component of the pace-of-life syndrome in tropical birds. Proc $R$ Soc Lond B Biol Sci (2005) 272:1715-20. doi:10.1098/rspb.2005.3155

68. Zysling DA, Garst AD, Demas GE. Photoperiod and food restriction differentially affect reproductive and immune responses in Siberian hamsters Phodopus sungorus. Funct Ecol (2009) 23:979-88. doi:10.1111/j.1365-2435. 2009.01572.x

69. Matson KD, Cohen AA, Klasing KC, Ricklefs RE, Scheuerlein A. No simple answers for ecological immunology: relationships among immune indices at the individual level break down at the species level in waterfowl. Proc $R$ Soc Lond B Biol Sci (2006) 273:815-22. doi:10.1098/rspb.2005.3376

70. Delers F, Strecker G, Engler R. Glycosylation of chicken haptoglobin: isolation and characterization of three molecular variants and studies of their distribution in hen plasma before and after turpentine-induced inflammation. Biochem Cell Biol (1988) 66:208-17. doi:10.1139/o88-028 
71. Versteegh MA, Schwabl I, Jaquier S, Tieleman BI. Do immunological, endocrine and metabolic traits fall on a single Pace-of-Life axis? J Evol Biol (2012) 25:1864-76. doi:10.1111/j.1420-9101.2012.02574.x

72. Koren L, Whiteside D, Fahlman Å, Ruckstuhl K, Kutz S, Checkley S, et al. Cortisol and corticosterone independence in cortisol-dominant wildlife. Gen Comp Endocrinol (2012) 177:113-9. doi:10.1016/j.ygcen.2012.02.020

73. Buchanan K, Goldsmith A. Noninvasive endocrine data for behavioural studies: the importance of validation. Anim Behav (2004) 67:183-5. doi:10.1016/j. anbehav.2003.09.002

74. Zar JH. Biostatistical Analysis. Upper Saddle River, NJ, USA: Prentice-Hall Press (2010).

75. Gaillard JM, Festa-Bianchet M, Yoccoz NG, Loison A, Toigo C. Temporal variation in fitness components and population dynamics of large herbivores. Annu Rev Ecol Syst (2000) 31:367-93. doi:10.1146/annurev.ecolsys.31.1.367

76. Hurley MA, Unsworth JW, Zager P, Hebblewhite M, Garton EO, Montgomery DM, et al. Demographic response of mule deer to experimental reduction of coyotes and mountain lions in southeastern Idaho. Wildl Monogr (2011) 178:1-33. doi:10.1002/wmon.4

77. Hamel S, Gaillard J, Festa-Bianchet M, Cote SD. Individual quality, early-life conditions, and reproductive success in contrasted populations of large herbivores. Ecology (2009) 90:1981-95. doi:10.1890/08-0596.1

78. Monteith KL, Schmitz LE, Jenks JA, Delger JA, Bowyer RT. Growth of male white-tailed deer: consequences of maternal effects. J Mammal (2009) 90:651-60. doi:10.1644/08-MAMM-A-191R1.1

79. Festa-Bianchet M, Jorgenson JT, Réale D. Early development, adult mass, and reproductive success in bighorn sheep. Behav Ecol (2000) 11:633-9. doi:10.1093/beheco/11.6.633

80. Barboza PS, Parker KL, Hume ID. Integrative Wildlife Nutrition. Berlin, Germany: Springer Berlin Heidelberg (2009). 342 p.

81. Agyemang K, Dwinger R, Little D, Leperre P, Grieve A. Interaction between physiological status in N'Dama cows and trypanosome infections and its effect on health and productivity of cattle in Gambia. Acta Trop (1991) 50:91-9. doi:10.1016/0001-706X(91)90001-Z

82. Graham AL, Hayward AD, Watt KA, Pilkington JG, Pemberton JM, Nussey DH. Fitness correlates of heritable variation in antibody responsiveness in a wild mammal. Science (2010) 330:662-5. doi:10.1126/science.1194878

83. Robinson DP, Klein SL. Pregnancy and pregnancy-associated hormones alter immune responses and disease pathogenesis. Horm Behav (2012) 62:263-71. doi:10.1016/j.yhbeh.2012.02.023

84. Coe CL. Immunity in primates within a psychobiological perspective. In: Demas GE, Nelson RJ, editors. Ecoimmunology. New York, USA: Oxford University Press (2012). p. 144-64.

85. Baker M, Schountz T, Wang L. Antiviral immune responses of bats: a review. ZoonosesPublicHealth(2013)60:104-16.doi:10.1111/j.1863-2378.2012.01528.x

86. Christe P, Arlettaz R, Vogel P. Variation in intensity of a parasitic mite (Spinturnix myoti) in relation to the reproductive cycle and immunocompetence of its bat host (Myotis myotis). Ecol Lett (2000) 3:207-12. doi:10.1046/j.1461-0248.2000.00142.x

87. Szekeres-Bartho J. Immunological relationship between the mother and the fetus. Int Rev Immunol (2002) 21:471-95. doi:10.1080/08830180215017

88. Buehler DM, Piersma T, Matson KD, Tieleman BI. Seasonal redistribution of immune function in a migrant shorebird: annual-cycle effects override adjustments to thermal regime. Am Nat (2008) 172:783-96. doi:10.1086/592865

89. Lifjeld JT, Dunn PO, Whittingham LA. Short-term fluctuations in cellular immunity of tree swallows feeding nestlings. Oecologia (2002) 130:185-90. doi:10.1007/s004420100798
90. De Coster G, De Neve L, Martin-Galvez D, Therry L, Lens L. Variation in innate immunity in relation to ectoparasite load, age and season: a field experiment in great tits (Parus major). J Exp Biol (2010) 213:3012-8. doi:10.1242/jeb.042721

91. Horrocks NP, Hegemann A, Ostrowski S, Ndithia H, Shobrak M, Williams $\mathrm{JB}$, et al. Environmental proxies of antigen exposure explain variation in immune investment better than indices of pace of life. Oecologia (2015) 177:281-90. doi:10.1007/s00442-014-3136-y

92. Ortego J, Espada F. Ecological factors influencing disease risk in eagle owls Bubo bubo. Ibis (2007) 149:386-95. doi:10.1111/j.1474-919X.2007.00656.x

93. Schmitt C, Garant D, Bélisle M, Pelletier F. Agricultural intensification is linked to constitutive innate immune function in a wild bird population. Physiol Biochem Zool (2017) 90:201-9. doi:10.1086/689679

94. Cook RC, Stephenson TR, Myers WL, Cook JG, Shipley LA. Validating predictive models of nutritional condition for mule deer. J Wildl Manag (2007) 71:1934-43. doi:10.2193/2006-262

95. Cook RC, Cook JG, Stephenson TR, Myers WL, McCorquodale SM, Vales DJ, et al. Revisions of rump fat and body scoring indices for deer, elk, and moose. J Wildl Manag (2010) 74:880-96. doi:10.2193/2009-031

96. Schwartz CC, Hubbert ME, Franzmann AW. Energy requirements of adult moose for winter maintenance. J Wildl Manag (1988) 52:26-33. doi: $10.2307 / 3801052$

97. Smith GD, French SS. Physiological trade-offs in lizards: costs for individuals and populations. Integr Comp Biol (2017) 57:344-51. doi:10.1093/icb/icx062

98. Pedersen AB, Babayan SA. Wild immunology. Mol Ecol (2011) 20:872-80. doi:10.1111/j.1365-294X.2010.04938.x

99. Jolles AE, Beechler BR, Dolan BP. Beyond mice and men: environmental change, immunity and infections in wild ungulates. Parasite Immunol (2015) 37:255-66. doi:10.1111/pim.12153

100. Adamo SA. How should behavioural ecologists interpret measurements of immunity? Anim Behav (2004) 68:1443-9. doi:10.1016/j.anbehav.2004. 05.005

101. Buehler DM, Piersma T, Irene Tieleman B. Captive and free-living red knots Calidris canutus exhibit differences in non-induced immunity that suggest different immune strategies in different environments. J Avian Biol (2008) 39:560-6. doi:10.1111/j.0908-8857.2008.04408.x

102. Viney M, Lazarou L, Abolins S. The laboratory mouse and wild immunology. Parasite Immunol (2015) 37:267-73. doi:10.1111/pim.12150

103. Owen-Ashley NT, Turner M, Hahn TP, Wingfield JC. Hormonal, behavioral, and thermoregulatory responses to bacterial lipopolysaccharide in captive and free-living white-crowned sparrows (Zonotrichia leucophrys gambelii). Horm Behav (2006) 49:15-29. doi:10.1016/j.yhbeh.2005.04.009

104. Abolins S, King EC, Lazarou L, Weldon L, Hughes L, Drescher P, et al. The comparative immunology of wild and laboratory mice, Mus musculus domesticus. Nat Commun (2017) 8:1-14. doi:10.1038/ncomms14811

Conflict of Interest Statement: The authors declare that the research was conducted in the absence of any commercial or financial relationships that could be construed as a potential conflict of interest.

Copyright $\odot 2018$ Downs, Boan, Lohuis and Stewart. This is an open-access article distributed under the terms of the Creative Commons Attribution License (CC BY). The use, distribution or reproduction in other forums is permitted, provided the original author(s) and the copyright owner are credited and that the original publication in this journal is cited, in accordance with accepted academic practice. No use, distribution or reproduction is permitted which does not comply with these terms. 